\title{
Feasibility and optimal design of a hybrid power system for rural electrification for a small village
}

\author{
Bankole Adebanji ${ }^{1}$, Gafari Abiola Adepoju², Paul Olulope ${ }^{3}$, Taiwo Fasina ${ }^{4}$, Oluwumi Adetan ${ }^{5}$ \\ $1,3,4,5$ Department of Electrical and Electronic Engineering, Ekiti State University, Nigeria \\ ${ }^{2}$ Department of Electronic and Electrical Engineering, Ladoke Akintola University of Technology, Nigeria
}

\begin{tabular}{l}
\hline Article Info \\
\hline Article history: \\
Received Apr 6, 2020 \\
Revised Jun 4, 2020 \\
Accepted Jun 17, 2020 \\
\hline
\end{tabular}

Keywords:

Feasibility study

Genetic algorithmn

Hybrid power system

Optimal sizing

Rural electrification

\begin{abstract}
A hybrid renewable energy system is at present accepted globally, as the best option for rural electrification particularly in areas where grid extension is infeasible. However, the need for hybrid design to be optimal in terms of operation and component selection serves as a challenge in obtaining reliable electricity at a minimum cost. In this work, the feasibility of installing a small hydropower into an existing water supply dam and the development of an optimal sizing optimization model for a small village-Itapaji, Nigeria were carried out. The developed hybrid power system (HPS) model consists of solar photovoltaic, small hydropower, battery and diesel generator. The optimal sizing of the system's components for optimum configuration was carried out using Genetic Algorithm. The hybrid model's results were compared with hybrid optimization model for electric renewable (HOMER) using correlation coefficient (r) and root mean square error (RMSE) to verify its validity. The results of the simulation obtained from the developed model showed better correlation coefficient ( $r$ ) of 0.88 and root mean square error (RMSE) of 0.001 when compared to that of HOMER. This will serve as a guide for the power system engineers in the feasibility assessment and optimal design of HPS for rural electrification.
\end{abstract}

Copyright $@ 2020$ Institute of Advanced Engineering and Science. All rights reserved.

\section{Corresponding Author:}

Bankole Adebanji,

Department of Electrical and Electronic Engineering,

Ekiti State University,

P.M.B.5363, Ado-Ekiti, Nigeria.

Email: bankole.adebanji@eksu.edu.ng

\section{Nomenclature}

$\begin{array}{llll}\text { Symbol } & \text { Meaninig } & \text { Symbol } & \text { Meaninig } \\ Q_{P} & \text { Rated volume flow rate }\left(\mathrm{m}^{3} / \mathrm{s}\right) & P_{P} & \text { Rated pump power (W) } \\ \eta_{p} & \text { Pump efficiency } & \mathrm{T} & \text { Rated pumping time in Secs. } \\ V_{R} & \text { Volume of the upper reservoir } & P_{L} & \text { Total load demand } \\ P_{S H P} & \text { Power output of the turbine } & V_{B} & \text { Battery bank voltage } \\ \rho_{\text {water }} & \text { Density of water }\left(1000 \mathrm{~kg} / \mathrm{m}^{3}\right) & & \text { Battery efficiency } \\ g & \text { Acceleration due to gravity }\left(9.8 \mathrm{~m} / \mathrm{s}^{2}\right) & S_{D} & \text { Battery autonomy or storage days } \\ H_{n e t} & \text { Effective head } & N_{S H P} & \text { Number of Hydro turbines } \\ Q & \text { Water discharge expected to pass through the turbine }\left(\mathrm{m}^{3} / \mathrm{s}\right) & N_{P V} & \text { Number of Solar panels } \\ P_{P V} & \text { Output power from the PV cell } & N_{B A T T} & \text { Number of battery banks } \\ P_{r-p v} & \text { Rated power at reference conditions } & S O C_{m a x} & \text { Max. State of Charge } \\ G_{r e f} & \text { Solar radiation }\left(1000 \mathrm{~W} / \mathrm{m}^{3}\right) \text { at reference } & S O C_{m i n} & \text { Min.State of Charge } \\ G & \text { Solar radiation in } \mathrm{kW} / \mathrm{m}^{2} & E_{g} & \text { Total energy content of oil } \\ T_{C} & \text { Cell temperature } & P_{B}(t) & \text { Batteryinput /output power } \\ k T & \text { Temperature coefficient of maximum power } & F C_{a n} & \text { Annual fuel cost } \\ C(t-1) & \text { Battery capacity at previous increment } & M C_{a n} & \text { Annual operation and maintenance cost }\end{array}$




$\begin{array}{ll}\text { Symbol } & \text { Meaninig } \\ C C_{a n} & \text { Annual capital cost of each of the component } \\ E C_{a n} & \text { Annual emission cost generated from DG } \\ (D O D)_{\max } & \text { Maximum battery Depth of Discharge } \\ (D O D)_{\min } & \text { Minimum battery Depth of Discharge }\end{array}$

\section{INTRODUCTION}

Renewable energy sources (RES) are now accepted globally to be the most effective solution in reducing global warming [1-4]. RES provides viable energy supply services that are affordable and dependable $[5,6]$. There is no single energy generating system (composing of RES alone) that is reliable and cost-effective due to its fluctuating nature. A hybrid system of RES optimally combined with other conventional energy resources like diesel generator (DG) will serve as a better alternative [2, 7].

Most of the villages in Nigeria are not connected to the grid [8-10]. This is due to the high cost of grid extension which makes the investment to be less competitive. The rural electrification agency (REA) has classified Nigeria as one of the potential areas where off-grid hybrid renewable energy can be used effectively for rural electrification [8, 9]. Off-grid rural populace deserves sustainable, reliable and cost-effective energy system to serve as an alternative to the environmentally unfriendly and expensive power supplied by the conventional energy system $[11,12]$.

Nigeria is naturally blessed with abundant RES which can be used for effective and rapid development of its rural areas $[8,9,13]$. The abundant RES (high solar irradiance, wind speeds, high stream flows of rivers and abundant biomass) in these areas can be harnessed to form a hybrid system for a reliable and sustainable power supply at reduced cost in the rural areas. However, the need for hybrid design to be optimal in terms of operation and component selection has been a major constraint in obtaining reliable electricity at a minimum cost. Hybrid renewable energy systems (HRES) need to be optimal in sizing to avoid oversizing which raises the cost or undersizing which may reduce the reliability of the system $[14,15]$. Succintly put, optimal sizing helps in determining the performance of the hybrid system in terms of cost and reliability [16-17]. Most of the available hybrid power system (HPS) models are very expensive, complex and not easily adaptable to suit local conditions for rural electrification [18, 19]. Hence, this work considered the feasibility of integrating small hydro power (SHP) plants into an existing water supply dam and the development of a SHP-Solar PV-BATT-DG HPS model for feasibility assessment and optimal sizing of hybrid renewable energy system in rural areas.

Some of the common types of softwares used for simulation and optimization of hybrid systems are HOMER, RETScreen, SOLES, INSEL, TRANSYS, HYBRID2, IMBY, SOLSIM, CREST, RAPSYS and SAM. Out of all these, HOMER developed by the National Renewable Energy Laboratory is the most widely used [5-7, 20-22]. So many works have been done on HRES, both off-grid [7-13, 16, 23-28] and grid connected [17, 22, 29]. Barakat et.al [22] examined the viability of grid-connected hybrid system consisting of Solar PV/Wind and Biomass in a rural village in Egypt using HOMER. Esan et.al [7] conducted a reliability assessment of an off-grid hybrid system consisting of Solar PV-BATT-DG system in a rural community-Lade II, Nigeria. The reliability of the results from HOMER simulations was validated using capacity outage table.

A techno-economic feasibility study was carried out in a remote area of Bangladesh by Masrur et al., [20]. A microgrid consisting of Solar PV, Wind, DG and BATT were considered to obtain the optimal energy system. A Solar PV/Wind/DG/BATT hybrid combination was selected as the best configuration for the village. The study concluded that the hybrid system is efficient in emission reduction. A study to identify the best solution for a recycled paper mill located in Rio Grande do soul, Southern Brazil for peak hours (19-22 hours) was conducted by [11]. The method considered the cost at peak hours only, the reliability was not considered. Somano and Shunki [23] developed a hybrid model consisting of SHP and Solar PV generators. The different combinations were analyzed for cost-effectiveness. The usage of DG or biomass was not considered as an alternative supply in case of non-availability of RES at a particular time.

Some authors also used artificial intelligence methods for their works [3, 5, 12, 14-19, 21-24, 29, 30]. A new methodology was introduced by Ogunjuyigbe et.al [12] using small split-diesel generators instead of a single big DG. Genetic algorithm (GA) was used for the simulation. Salkuti [31] carried out an optimal operation of grid-connected micro grids consisting of wind, Solar PV, BATT system, electric vehicles and demand response. Simulations were performed using GAMS software. Jyothi et al [24] conducted a research on optimal management on a stand-alone of Solar PV/BATT system consisting of Solar PV array, BATT, inverter and $\mathrm{AC}$ loads using maximum power point tracker (MPPT) technique in a MATLAB/Simulink environment. The work proposed an optimal energy management for improved performance of the Solar PV system.

Even though, several authors have worked on HPS technology, very few papers have been published on Pumped hydro-SHP-Solar PV-BATT-DG hybrid system using water supply infrastructures [5, 7, 10]. 
The level of accuracy of the models described above depends largely on the assumptions made [4]. Looking critically at the aforementioned related works, it can be seen that most of the works or studies on HPS have been designed to simulate and/or optimize PV, wind, DG, e.t.c.Very few of the software-based models (except HOGA and HOMER) have provisions for small hydroelectric energy component. This work considered the following points:

- Feasibility of Pumped hydropower and integration of small hydro power (SHP) plants into an existing water supply dam.

- Design of an optimal HPS model that determines the size and the type of HPS combinations that is most suitable for an area with due consideration to cost and reliability.

\section{RESEARCH METHOD}

\subsection{Data acquisition and description of the study area}

Data for water supply and demand were obtained from Ekiti State Water Corporation, Ado-Ekiti. Reservoir capacity, river head, flow gauge heights, stream flow rate and climate data were obtained from benin-owena river basin development authority (BORDA) Benin-city and Akure Airport Meteorological station, Nigeria [10,32,33]. The data used are shown in the appendices 1 and 2. The study area selected for this work is Ele river water supply dam, Itapaji-Ekiti $\left(7^{\circ} 49^{\prime} \mathrm{N}, 5^{\circ} 23^{\prime} \mathrm{E}\right)$, Nigeria. Total annual rainfall ranges between 1350-1400 mm, while temperature ranges between $32^{\circ} \mathrm{C}-35^{\circ} \mathrm{C}$ (dry season) and $21^{\circ} \mathrm{C}-22^{\circ} \mathrm{C}$ (wet season) [10]. The load demand for the area was obtained through the use of questionaires. The daily load profile for the study area is as shown in Figure 1.

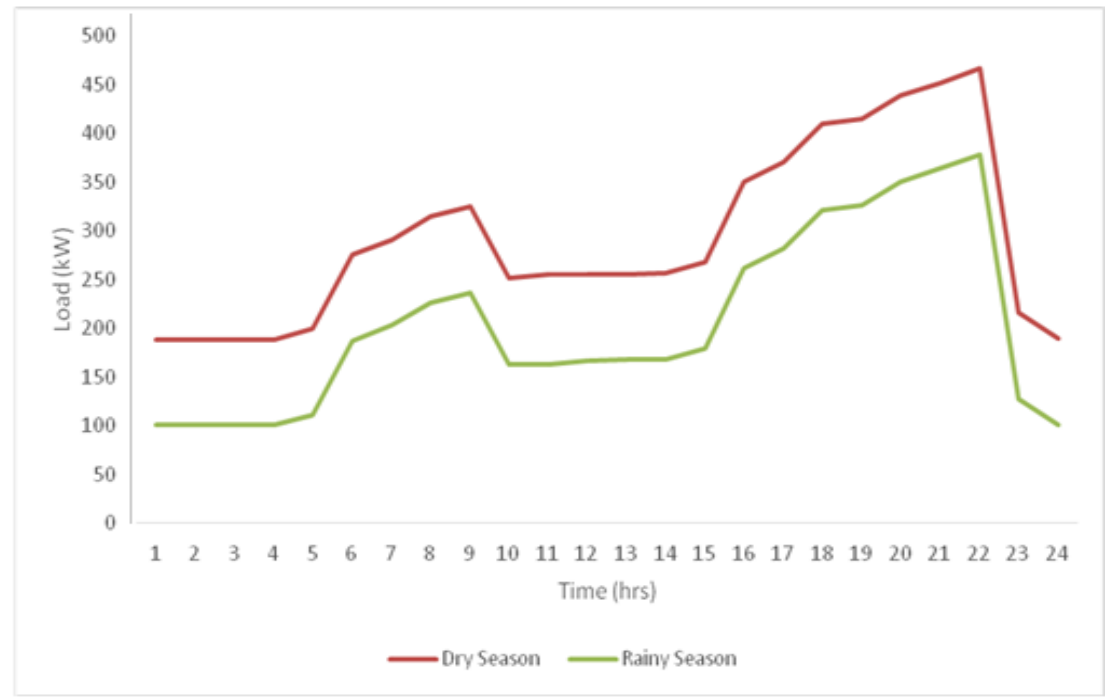

Figure 1. Daily average load profile for dry (January, 2019) and raining (September, 2019) seasons for Itapaji Ekiti

\subsection{Feasibility study of SHP integration and RES evaluation}

The feasiblility study was carried out in order to make unbiased technical hydrological decision on the viability of the dam. The approach adopted was to create a suitable head with a combination of a sustainable high flow rates with steep gradients for SHP generation. Since the dam was already being used for water supply, the head and stream flow was adopted. The flow duration curve (FDC)-hydrograph with daily data was compiled for the past thirty years (1989-2019) [33].

\subsection{Pumped hyropower storage (PHS) system}

Pumped hydropower storage can be effectively used to mitigate the effect of interminency in other RES like Solar PV, wind and others. It is the lowest cost energy option [34]. In order for $1 \mathrm{MW}$ rated power to be raised to a rated head in an upper reservoir, the volume flow rate is calculated as in (1) [34].

$$
Q_{p}=\frac{P_{p} \times \eta_{p}}{g \times \rho \times h}
$$


The upper reservoir required volume is as given in (2)

$$
V_{R}=Q_{P} \times T
$$

The meanings of all the symbols are as given in the nomenclature (pp.9).

\subsection{Mathematical models of the HPS components}

The steps to achieve the modeling of each hybrid component are as outlined in the following sub-sections.

\subsubsection{Small hydropower (SHP) generator}

The electrical power output of the SHP unit is given as in (3) [23].

$$
P_{S H P}=\eta_{h} \rho_{\text {water }} g H_{n e t} Q
$$

\subsubsection{Solar photovoltaic (PV) model}

The maximum power output from the PV cell, $P_{P V}$ can be calculated as in (4) [29].

$$
P_{P V}=P_{r-P V}\left[\frac{G}{G_{r e f}}\right]\left[1+k T\left(T_{C}-T_{r e f}\right)\right]
$$

\subsubsection{Battery bank model}

The battery capacity, $C(t)$ at a point in time $t$, is calculated as in (5) [16].

$$
\begin{aligned}
& C(t)=C(t-1)-\eta_{\text {batt }}\left(\frac{P_{B}(t)}{V_{B U S}}\right) \Delta t \\
& P_{B}(t) \text { is as in }(6) \\
& P_{B}(t)=E_{g}(t)-E_{i}(t)
\end{aligned}
$$

The value is positive when the battery is charging.

\subsubsection{Diesel generator (DG) model}

The diesel generator is an energy conversion system from fuel to electricity with a conversion efficiency of, $\eta_{D G}$ so that it can be described as in (7) $[25,30]$.

$$
E_{D G}=\eta_{D G} E_{f f}
$$

A linear model has been assumed for the fuel consumption rate $(F)$ in litres/hour of operation by the DG $[25,30]$ given in $(8)$.

$$
F=\left(0.246 \times P_{\text {out }}\right)+\left(0.08415 \times P_{\text {Ngen }}\right) \text { litres } / \text { hour }
$$

The fuel cost, $C_{\text {fuel }}$ can be calculated using the formula as in (9)

$$
C_{\text {fuel }}=C_{\text {diesel }} F\left(R_{s}\right)
$$

\subsection{Optimal design criteria for the HPS model}

\subsubsection{Problem formulation}

The objective function here is an economic function that is constrained in a technical or reliability function. The problem was modeled according to the loss of power supply probability (LPSP) and total annualised cost system (ACS). The ACS is as given in equation (10) $[14,29,35]$ while the LPSP $[14,29]$ is as expressed in (10)

$$
A C S=C C_{a n}+R C_{a n}+M C_{a n}+F C_{a n}+E C_{a n}
$$




$$
L P S P=\frac{\sum\left(P_{L}-P_{S H P}-P_{P V}+P_{S O C_{\min }}+P_{D G}\right)}{\sum P_{L}}
$$

This is subject to an inequality constraint as (12)

$$
L P S P_{\text {Min }} \leq L P S P \leq L P S P_{M a x}
$$

Reliability evaluation is carried out in the worst conditions as given in (13)

$$
P_{L}(t)>P_{R}(t)
$$

\subsubsection{Constraints}

In order to solve the optimization problem, all the constraints in equations (14-18) must be satisfied [33].

- Power balance constraint,

$$
P_{S H P}(t)+P_{P V}(t)+P_{B A T T}(t)+P_{D G}(t) \geq(1-R) P_{d}(t)
$$

- Battery capacity constraint,

$$
\mathrm{SOC}_{\min } \leq \mathrm{SOC}(\mathrm{t}) \leq \mathrm{SOC}_{\max }
$$

- Non-negativity constraints,

$$
\begin{aligned}
& 0 \leq \mathrm{N}_{\mathrm{PV}, \mathrm{P}} \leq \mathrm{N}_{\mathrm{PV}, \mathrm{Pmax}} \\
& 0 \leq \mathrm{N}_{\mathrm{SHP}} \leq \mathrm{N}_{\mathrm{SPV} \max } \\
& 0 \leq \mathrm{N}_{\mathrm{BAT}, \mathrm{P}} \leq \mathrm{N}_{\mathrm{BAT}, \mathrm{Pmax}}
\end{aligned}
$$

\subsubsection{Assumptions}

- It is assumed that the HPS will work continuously for twenty-four hours daily

- The electrical load and the RES are constant within one-hour time step

\subsection{Optimization procedure}

Input parameters for the system optimization are the installation cost, replacement costs, operation and maintenance costs of all components, discount rate, the efficiency, lifetime of all the components and lifetime of the projects, specifications of all the components, hourly load demand of the proposed site and the hourly meteorological data. The different mathematical models of the system components developed in the previous sections were used for simulating the HPS. The power outputs from the SHP turbine were calculated using power (3) taking the average stream flows as input. The power outputs from the Solar $\mathrm{PV}$-arrays were calculated at an hourly basis from the power equation (4) using the hourly solar irradiance values as the input. The renewable energy was added together and compared with the hourly load demand. The battery bank and the DG operate depending on whether the total RES is equal, less or more than the load demand. The flowchart for this simulation is as shown in Figure 2.

Genetic algorithm (GA) was utilized in this simulation to determine the optimal configuration. GA is very flexible and has better efficiency than classical methods. The four decision variables considered are number of SHP turbines, $\left(\mathrm{N}_{\mathrm{SHP}}\right)$, number of PV-panels, $\left(\mathrm{N}_{\mathrm{PV}}\right)$ and number of battery bank and the DG capacity number, $\left(\mathrm{P}_{\mathrm{DG}}\right)$. The population structure is $\left[N_{S H P}, N_{P V}, N_{B A T T}, P_{D G}\right]$. The annual power supply simulation was performed repeatedly for each chromosome until it reached the maximum generation after setting the initial population. In every generation, the best chromosome was preserved and compared with the best chromosome in the next generation. The best chromosome in the final generation is considered as the optimum parameters value of the hybrid system. GA based MATLAB m-file code was developed to determine the optimal configuration of small hydro-photovoltaic-diesel hybrid system of the case study. 


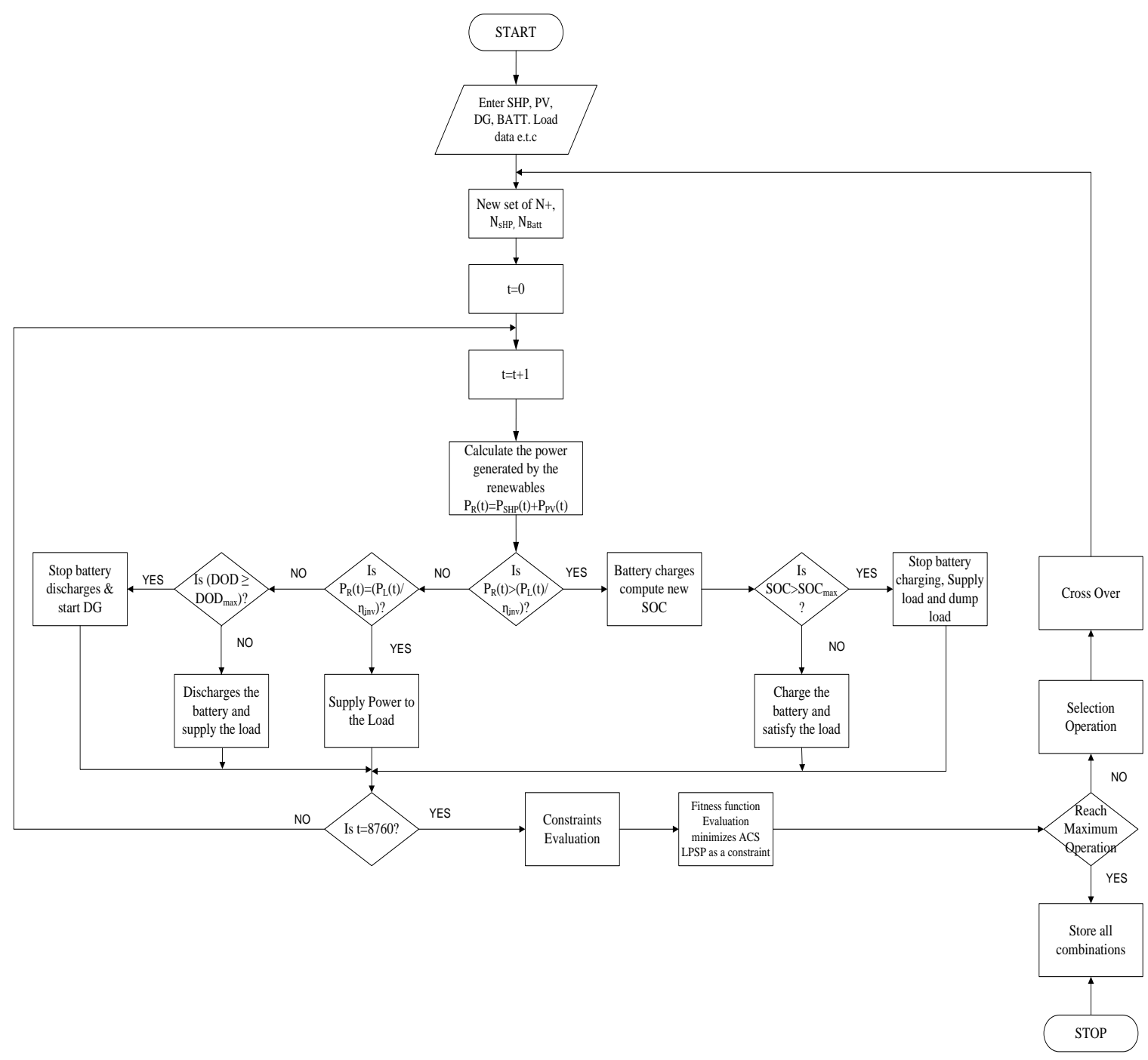

Figure 2. Flowchart of the hybrid power system model

\subsection{Model validationand performance evaluation of the HPS model}

HOMER is the most commom cost analysis and validation test for stand alone hybrid system [5, 7, 23, 35]. The HPS model was then validated by comparing its results with that of HOMER, using it as a benchmark [36]. The simulation was done in MATLAB environment. The data published by Ani and Nzeako [13] were used as the validating data. In order to measure the difference between the HOMER and the developed model, coefficient of correlation (r) and root mean square error (RMSE) were used to measure the closeness of the results of the two models. The new model was then applied to the case study area to evaluate its performance.

\section{RESULTS AND DISCUSSION}

\subsection{Feasibility study for small hydropower plant integration}

It was observed that during the raining season (April-October) there were enough hydro sources to run the turbine. The stream flow reaches its peak of 15,500 L/S in September. The hydro power potential is to generate $2.70 \mathrm{MW}$ at maximum discharge of $23.24 \mathrm{~m}^{3} / \mathrm{s}, 966 \mathrm{~kW}$ at average annual discharge of $8.33 \mathrm{~m}^{3} / \mathrm{s}$. and generate $206.5 \mathrm{~kW}$ at minimum discharge of $1.78 \mathrm{~m}^{3} / \mathrm{s}$ during dry season with a reservoir capacity balance of $0.12410^{9} \mathrm{~m}^{3} /$ year. The estimated power demand for the village as at September, 2019 is $621 \mathrm{~kW}$. The demand forecast for year 2028 is $1210 \mathrm{~kW}$. When the hydro turbines generate $206.5 \mathrm{~kW}$ at minimum discharge during dry season, the power deficit is 414.5 (621-206.5) $\mathrm{kW}$. Consequently, there is need to complement the hydro power source with another renewable energy source-solar PV. 


\subsection{HPS model validation results}

The optimal sizing results for both HOMER and the developed model is shown in Table 1. The simulated results obtained from HOMER showed a good correlation (correlation coefficient (r) is 0.88 while the root mean square error (RMSE) is 0.001) with those obtained from the developed model. The little difference in the results is due to the different modeling approaches adopted in the modeling of the generators. However, these do not have significant effect on the overall results. Generally, the results from the developed model were comparable to those obtained using HOMER. The developed model gives higher priority to the hydro turbine than the solar panel due to the higher cost of solar panel. This is especially more economical when a dam-based SHP is used. The developed model is simple, more reliable and can easily be modified according to the need of a particular project.

Table 1. Validation results

\begin{tabular}{lll}
\hline Description & HOMER & Developed model \\
\hline SHP $(\mathrm{kW})$ & 10.7 & 11 \\
PV panel $(\mathrm{kW})$ & 10.3 & 10 \\
DG $(\mathrm{kW})$ & 16 & 16 \\
BATT $(\mathrm{kWhr})$ & 6.9 & 7 \\
R.F. $(\%)$ & 0.68 & 0.70 \\
COE $(\$ / \mathrm{kWhr})$ & 0.267 & 0.268 \\
LPSP & 0.0054 & 0.0045 \\
\hline
\end{tabular}

\subsection{Application of the model to the study area-Itapaji}

The optimal sizing results of the different combinations at peak load demand are as presented in Table 2 while the average monthly electric power production for the three hybrid combinations were as presented in Figures 3-5.

Table 2. Optimal sizing result for the three Hybrid combinations at Peak load demand

\begin{tabular}{cccc}
\hline Component & Solar PV-BATT-DG & SHP-BATT-DG & $\begin{array}{c}\text { Pumped Hydro-Solar } \\
\text { PV-BATT-DG }\end{array}$ \\
\hline Pumped hydro $(\mathrm{kW})$ & & & 960 \\
SHP $(\mathrm{kW})$ & & 960 & \\
Solar PV $(\mathrm{kW})$ & 640 & 320 & 64 \\
DG $(\mathrm{kW})$ & 400 & 200 & 0 \\
BATT $(\mathrm{kWhr})$ & 1000 & 1000 & 0 \\
COE $(\mathbf{k W h r})$ & $\mathbf{0 . 3 0 9}$ & $\mathbf{0 . 1 8 7}$ & $\mathbf{0 . 0 6 8}$ \\
RF $(\mathbf{\%})$ & $\mathbf{0 . 3 8}$ & 0.0004 & $\mathbf{0 . 9 8}$ \\
LPSP & 0.0004 & 675,860 & 0.0001 \\
ACS $(\mathbf{\$})$ & 785,400 & 24,774 & 43,313 \\
Operating cost $(\mathbf{\$})$ & 44,985 & & 12,572 \\
\hline
\end{tabular}

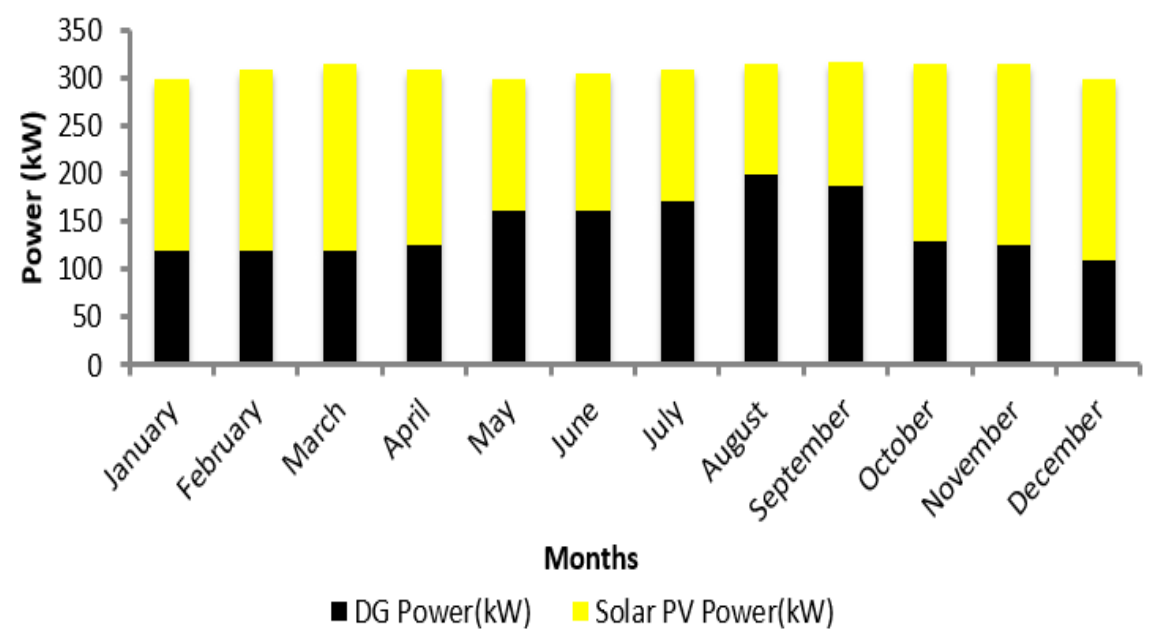

Figure 3. Monthly average electric production for the solar pv-batt-dg hybrid system at peak load demand 


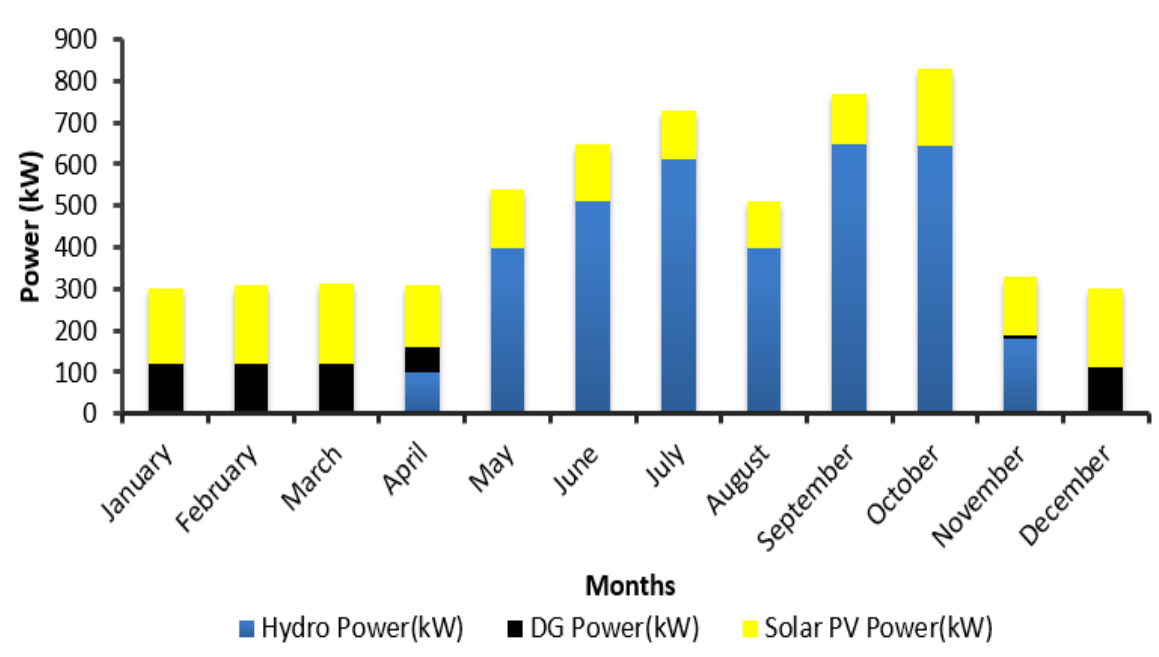

Figure 4. Monthly average electric production for the SHP-Solar PV-BATT-DG Hybrid system at peak load demand

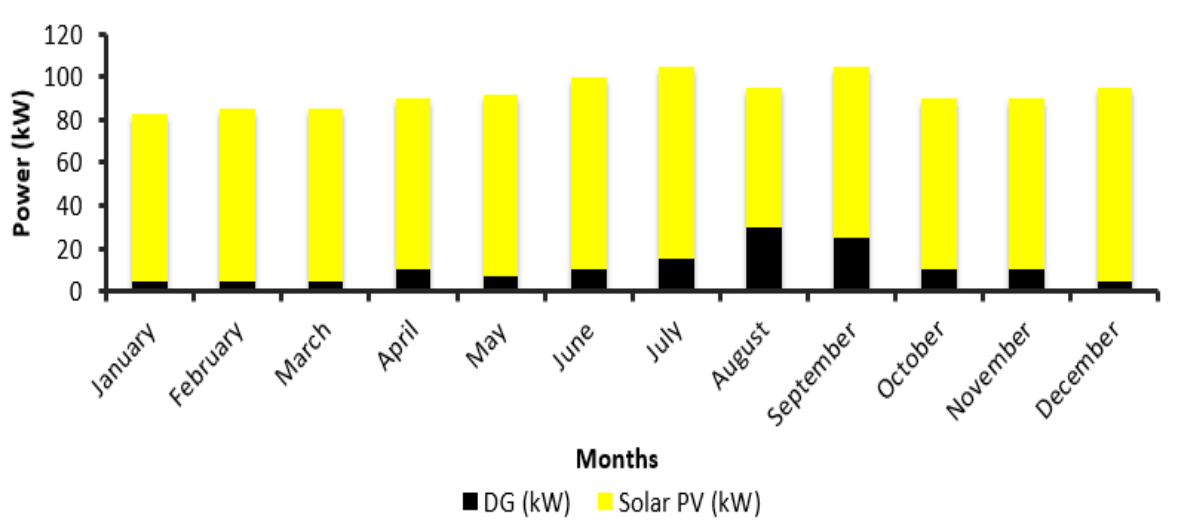

Figure 5. Monthly average electric production for the Pumped hydro-Solar PV-BATT-DG Hybrid system at peak load demand

\subsubsection{Solar PV-BATT-DG hybrid combination}

The Solar PV contributed 1,666,076 kWhr per year while the DG contributed 1,034,304 kWhr per year. The DG consumed \$451,687 litres per annum. The COE at peak load and low load demand was 0.309. The solar PV and DG sizing values are very high compared to when the SHP and pumped hydro systems were used. It can be seen from Figure 3 that the hybrid systems made use of both the Solar PV and the DG in the year. The hybrid system made less use of the DG during the dry season (October-March) when there is high Solar irradiation and made much use of the DG during the raining season (April-September) when there is less solar irradiation. This accounted for a very high operating cost. The COE was higher than any other combinations considered in this work. The cost may be too high for the rural dwellers.

\subsubsection{SHP-Solar PV-BATT-DG hybrid combination}

The hydro turbine contributed 3,023,323 kWhr per year; PV contributed 726,065 kWhr per year contributed while the DG contributed $524,634 \mathrm{kWhr}$ per year. The DG consumed \$233,091 litres per annum. The Solar PV and the DG sizing values reduced accordingly. This is because of the high SHP sizing value which has lower annualized cost than other hybrid components. It can be seen from Figure 4 that the hybrid systems made use of DG during the months of November-April (dry season with relatively low stream flow). This accounted for an increase in the cost of production due to high cost of diesel. However, between May and October ((raining season with relatively high stream flow) there were enough hydro sources to turn the turbine. 


\subsubsection{Pumped hydro-Solar PV-BATT-DG hybrid combination}

The pumped hydro contributed 5,749,422 kWhr per year and the PV contributed 13,375 kWhr per year. The pumped hydro-solar PV-BATT-DG hybrid system showed a better improvement in terms of annualized cost, COE, RF and operating cost. It can be observed from Table 2 that the DG and the BATT made no contribution to the electricity production. This is because the pumped hydro system produced a constant supply throughout the year. This is due to the fact that the pumped water was used and recycled. During low load demand, the water was pumped and stored in the storage system but when there is peak demand, the water is used to meet the demand. Thus, this resulted in a very low operating cost, and thereby lessens environmental effects. The cost of generating the hydro is the least when compared with solar PV and DG. The COE for both the peak and low load demand scenarios was 0.068 (with RF of 0.98). This will indeed be more affordable to the rural dwellers.

\section{CONCLUSION}

This work considered the feasibility of integrating SHP plants into an existing water supply dam and the development of a SHP-Solar PV-DG HPS model for feasibility assessment and optimal sizing of Hybrid renewable energy system in rural areas. Optimal sizing of the system's components for optimum configuration was done using Genetic Algorithm. The hybrid model's results were compared with those obtained from HOMER to verify its validity. The developed model simulation results compared favourably and very close to those obtained using HOMER. This will serve as a guide for the power system engineers in the feasibility assessment and optimal design of HPS for rural electrification.

\section{APPENDIX}

Appendix 1. Detailed parameters of the components [10,33]

\begin{tabular}{|c|c|c|c|}
\hline \multicolumn{2}{|c|}{ Solar PV specification } & \multicolumn{2}{|c|}{ SHP Parameters } \\
\hline Module Type & RNG 160P & Nominal power $(\mathrm{kW})$ & 96 \\
\hline$P_{\operatorname{Max}}(W)$ & 160 & Available Head & 21.6 \\
\hline$V_{O C}(V)$ & 22.8 & Design flow rate & $4.33 \mathrm{~m}^{3} / \mathrm{s}$ \\
\hline$I_{S C}(A)$ & 9.47 & Turbine efficiency & $75 \%$ \\
\hline Module efficiency & $14.05 \%$ & Life time & $25 \%$ \\
\hline Dimention & $(58.3 \times 26.5 \times 1.4) \mathrm{m}$ & \multicolumn{2}{|c|}{ DG Parameters } \\
\hline NOCT & $46^{\circ} \mathrm{C}$ & Size & $200 \mathrm{~kW}$ \\
\hline$V_{m p}$ & 18.6 & Quantity & 2 \\
\hline$I_{m p}$ & 8.6 & Life time & $20,000 \mathrm{hrs}$ \\
\hline Life time & 25 years & Price & $0.884 \$$ /litre \\
\hline \multicolumn{2}{|c|}{ Battery specifications } & \multicolumn{2}{|c|}{ Converter details } \\
\hline Minimum lifetime & 4 years & & \\
\hline Initial State of Charge (SOC) & $100 \%$ & Size & $791 \mathrm{~kW}$ \\
\hline Depth of Discharge (DOD) & $80 \%$ & Life time & 15 years \\
\hline Voltage & $12 \mathrm{~V}$ & Inverter efficiency & $90 \%$ \\
\hline Efficiency & $80 \%$ & Rectifier efficiency & $85 \%$ \\
\hline
\end{tabular}

Appendix 2. Detailed Cost parameters of the components (Initial, replacement and maintenance costs)

\begin{tabular}{cccc}
\hline Component & Initial cost & Replacement cost & Operational and maintenance cost \\
\hline PV module & $2500 \$ / \mathrm{kW}$ & $2500 \$ / \mathrm{kW}$ & $\$ 5$ \\
Hydro turbine & $\$ 430,247$ & $\$ 430,247$ & $\$ 10,308$ \\
Diesel Generator & $503.08 \$ / \mathrm{kW}$ & $503.08 \$ / \mathrm{kW}$ & $15 \$ / \mathrm{hr}$ \\
Battery & $1710 \$ / \mathrm{kAh}$ & $1710 \$ / \mathrm{kAh}$ & $76 \$ / \mathrm{kAh}$ \\
Converter & $\$ 8043$ & $\$ 8043$ & $\$ 0$ \\
\hline
\end{tabular}

\section{ACKNOWLEDGEMENTS}

The authors expressed their gratitudes to all the staff and students of Ekiti State University, Ado-Ekiti, Nigeria and Ladoke Akintola University of Technology, Ogbomosho, Nigeria for their invaluable contributions towards the success of the work.

\section{REFERENCES}

[1] A. Hepbasli, "A key review on exergetic analysis and assessment of renewable energy sources for a sustainable future," Energy Reviews, vol. 2, no. 2, pp. 593-661, 2008. 
[2] D. S. Ashok, "Optimized model for community-based hybrid energy system," Renewable energy, vol. 2, pp. 1155-1164, 2007

[3] S. K. Ramoji and B. J. Kumar, "Optimal economical sizing of a PV-wind hybrid energy system using genetic algorithm and teaching learning based optimization," International Journal of Avanced Research in Electrical, Electronics and Instrumentation Engineering, vol. 2, pp. 34-56, 2014.

[4] T. R. Ayodele and A. S. O. Ogunjuyigbe, "Mathemathical methods and software tools for designing and economic analysis for hybrid energy systems," International Journal of Renewable Energy, vol. 9 pp. 57-68, 2014.

[5] A. Acakpovi, "Original framework for optimizing hybrid energy supply," Journal of Energy, vol. 2, pp. 1-10, 2016.

[6] M. Kdair Abd, "Economic viability and profitability assessments of WECS," International Journal of Electrical and Computer Engineering (IJECE), vol. 10, no. 2, pp. 1220-1228, 2020.

[7] A. B. Esan, A. F. Agbetuyi, O. Ogboreda, K. Ogbeide, A. A. Awelewa and A. E. Afolabi, "Reliability assessment of islanded hybrid PV-DG-BATT system for a typical rural community in Nigeria," Heliyon, pp. 1-13, 2020.

[8] Nigeria Energy Forum, "Accelerating access to sustainable energy for all-scaling up sustainable ruralelectrification in Nigeria," Lagos, 17th-18th April, 2018.

[9] D. E. Babatunde, O. M. Babatunde, M. U. Emozemuwire, I. H. Denwigwe, T. E. Okharedia and O. J. Omodora, "Feasibility analysis of an off-grid photovoltaic-battery energy system for a farm facility," International Journal of Electrical and Computer Engineering (IJECE), vol. 10, no. 3, pp. 2874-2883, 2020.

[10] B. Adebanji, "Development of a hybrid power system model for rural electrification," an unpublished Ph.D thesis submitted to the Department of Electronic and Electrical Engineering, Ladoke Akintola University of Technology, Ogbomoso, Nigeria, 2019.

[11] A. Beluco, C. P. Colvara, I. E. Texeira and A. Beluco, "Feasibility study for power generation duringpPeak hours with a hybrid system in a recycled paper mill," Computational Water, Energy and Environmental Engineering, vol. 2, pp. 45-53, 2013.

[12] A. S. O. Ogunjuyigbe, T. R. Ayodele, and O. A. Akinola, "Optimal allocation and sizing of PV/wind/splitDG/BATThybrid system for minimizing life cycle cost,carbon emission and dump energy of remote residential building," Applied Energy, vol. 9, pp. 153-171, 2016.

[13] V.A. Ani,and A.N. Nseako, "Potentials of optimized hybrid system in powering off-gridmacro base transmitter station site," International Journal of Renewable Energy Research, vol. 3, pp. 861-871, 2013.

[14] P. Suhane, S. Rangneker and A. Mittel, "Optimal sizing of hybrid energy system using ant colony optimization," International Journal of Renewable Energy Research, vol. 4, pp. 683-688, 2014.

[15] T. Honerica and H. Tawanda, "A technical model for optimizing PV/diesel/battery hybrid power systems," CSIR Proceedings Science real and Relevant Conference, pp. 23-34, 2010.

[16] Koutroulis, E., Kolokosa, D., Potirakis, A., and kalaitzakis, K., "Methodology for optimal sizing of stand alone photovoltaic/wind-generator systems using genetic algorithms," Solar Energy, vol. 80, no. 2, pp. 1072-1088, 2006

[17] R. J. Kumar and M. S. Kalavathi, "Optimal sizing of Satin Bowerbird optimization," International Journal of Innovative Technology and Exploringgrid-connected hybrid PV/wind/battery power system using Engineering, vol. 8, no. 4, 2019.

[18] H. Hildebrand, "Planning tool for small hydropower development," Presented at the Technical University of Georgia in Tbilis on behalf of UNESCO at the International Hydropower Association, pp. 23-57, 1997.

[19] T. Khatib, A. Mohammed and K.Sopian,"A software tool for optimal sizing of PV systems in Malaysia," Modelling and Simulations in Engineering, vol. 3, no. 2, pp. 1-11, 2012.

[20] H. Masrur, H. O. R. Howlader, M. E. Lofty, K. R. Khan, J. M. Gerrero and T. Senjyu, "Analysis of technoeconomic environmental suitability of an isolated microgrid system located in a remote island of Bangladesh," Sustainability, vol. 12, pp. 1-27, 2020.

[21] O. Skarstein and K. Ulhen, "Design considerations with respect to long term diesel saving in wind/diesel plants," Wind Engineering, vol. 13, pp. 136-142, 1989

[22] S. Barakat, M. M. Samy, M. B. Eteiba and Wabi, "Viability study of grid-connected PV/wind/biomass hybrid energy system for small village in Egypt," vol. 2, no. 2, pp. 1-5, 2016.

[23] G. Z. Somano and G. Shunki, "Design and modeling of hybrid PV-micro hydro power generation case study Jimma zone," American Journal of Electrical Power and Energy System, vol. 2, pp. 43-48, 2017.

[24] V. M. Jyothi, T. V. Muni and SVNL Lalithna, "An optimal energy management system for PV/battery stand alone," International Journal of Electrical and Computer Engineering (IJECE), vol. 6, no. 6, pp. 2538-2544, 2016.

[25] A.Vahabzadeh, F. Separi, M. Samkush and M. Jafari "Optimal sizing of hybrid energy resources for electricity distant rural areas of Iran," CIRD Workshop-Lisbon, pp. 29-30, 2007

[26] S. A. Shezen, S. J. Wei, M. A. Kibria, K. R. Ullan, R. Saidu, W. T. Chong and R. K. Akitur, "Performance analysis of an off grid wind-PV-DG-BATT hybrid energy system feasible for remote area," Journal of CleanerProduction, vol. 4, no. 1, pp. 121-132, 2016.

[27] K. Merugaperumal, D. Ajay and P. Raj, "Feasibility design and techno-economic analysis of hybrid renewable energy system for rural electrification," Solar Energy, vol. 188, pp. 1068-1083, 2019.

[28] O. Kour, "Technical and economic analysis of a hybrid power system: A case study for a village in India," International Journal for Research in Applied Science and Engineering Technology, vol. 6, no. 5, pp. 2043-2049, 2019.

[29] Hungxing, "Optimal sizing method for stand-alone hybrid solar-wind system with LPSP technology by using genetic algorithm," Solar Energy, vol. 82, pp. 354-367, 2008.

[30] A. K. Dauid, "Simulation of a hybrid power system consisting of wind turbine, PV, storage battery and diesel generator; Design, optimization and economical evaluation," International Journal of Energy Engineering, pp. 56-61, 2011. 
[31] S. R. Salkuti, "Optimal operation management of grid-connected microgrids under uncertainty," Indonesian Journal of Electrical and Computer Science (IJEECS), vol. 16, no. 3, pp. 1163-1170, 2019.

[32] BORDA, "Benin-Owena River Basin Development Authority," Hydrological Year Book, 2011

[33] FMWR, "Pre-feasibility reports on SHP projects," Federal Ministry of Water Resources-Benin-Owena River Basin Development Authority, pp. 1-54, 2007.

[34] A. Al-Garallah, "Design of a pumped hydroelectric energy storage (PHES) system for Jordan," Jordan University, 2017.

[35] R. T. Thahab and A. T. Thahab, "Electrical power generation through concentratedsolar technology for Southern Cities of Iraq," International Journal of Electrical and Computer Engineering (IJECE), vol. 10, no. 4, pp. 3789-3800, 2020.

[36] HOMER, “The micropower optimization model, Homer, Energy,” Version 268, 2009.

\section{BIOGRAPHIES OF AUTHORS}
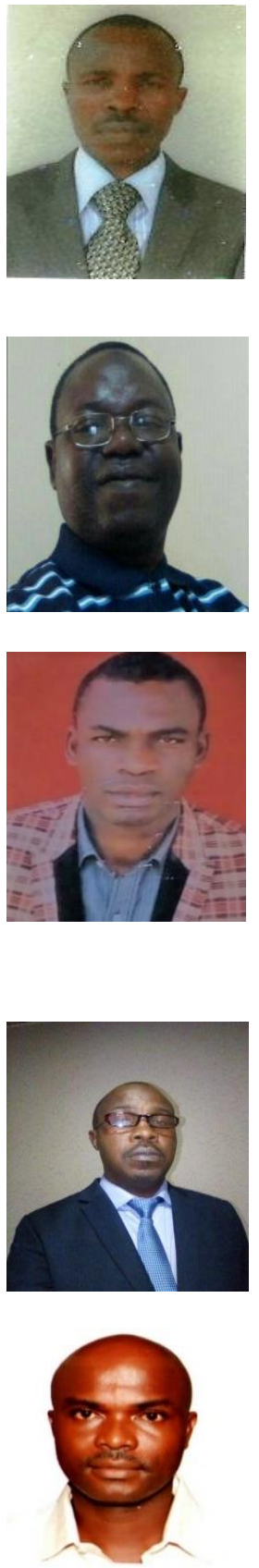

Bankole Adebanji received the degree of B.Eng. in Electrical and Electronic Engineering in 1997 from the then Ondo State University, Ado-Ekiti, Ekiti State, Nigeria (now Ekiti State University, Ado-Ekiti ), M.Tech. degree (Electronic and Electrical Engineering) and Ph.D degree ( Power System Engineering and Machine) from Ladoke Akintola University of Technology (LAUTECH), Ogbomoso, Nigeria in 2010 and 2019 respectively. His researh interest are Renewable energy, Power system engineering, Hybrid, Small hydro and optimization. He is a resgistered COREN Engineer and a member of Nigerian Society of Engineers (MNSE). He is currently lecturing in the Electrical and Electronic Engineering department of Ekiti State University, Ado-Ekiti, Nigeria.

Adepoju Gafari A. received the degree of B.Tech. in Electronic and Electrical Engineering from the Ladoke Akintola University of Technology, Ogbomoso in 1997; M.Sc. degree from University of Lagos and Ph.D. from Ladoke Akintola University of Technology, Ogbomoso in 1999 and 2011 respectively. He is currently a Professor of power system Engineering in the Department of Electronic and Electrical Engineering, Ladoke Akintola University of Technology, Ogbomoso. His research interests are: power system Engineering and Machines; Power Electronic Converters and Electric Drives; and Renewable Energy Engineering.

Olulope P.K had been a University lecturer since June 2002 till date at the Ekiti State University, Nigeria. He completed his Doctoral degree in Power System Engineering from the University of Cape Town, South Africa. He completed his Master degree program (M.Eng.) in Electrical and Electronic Engineering from the University of Benin, Edo State, Nigeria and Bachelor of Engineering (B.Eng) at Ekiti State University in 2005 and 2002 respectively. He is a registered member of the Institute of Electrical and Electronics Engineers (IEEE), a registered member of the Council for the Regulation of Engineering in Nigeria (COREN) and the Nigeria Society of Engineers (NSE).His Research interest is on the application of Computational intelligence to power system, integration of renewable energy and distributed generation into power grid.

Fasina Emmanuel Taiwo received B. Eng. from Ekiti State University Ado Ekiti, Nigeria in 1998 and M. Tech. from Ladoke Akintola University of Technology, Ogbomoso, Nigeria in 2012. He completed his Ph.D. from Cardiff University, UK in 2019. He is a registered member of the Council for the Regulation of Engineering in Nigeria (COREN) and the Nigeria Society of Engineers (NSE). He is currently a lecturer in Ekiti State University, Ado Ekiti, Nigeria. His main interest includes power system analysis and control, Integration of distributed generation, storage, and electric vehicle into the grid, localised energy systems, deregulation and electricity transmission pricing.

Oluwumi Adetan holds a Bachelor of Engineering (B.Eng.) degree in Electrical and Electronic Engineering from the then Ondo State University, Ado-Ekiti, Nigeria (Now Ekiti State University, Nigeria), a Master of Engineering (M.Eng.) degree in Electrical and Electronic Engineering (Communication Option) from the Federal University of Technology, Akure, Nigeria. He completed in 2014 his Doctoral degree in Electronic Engineering from the University of KwaZulu-Natal, South Africa. His research interests are on radio wave propagation and to study the effects of rain on microwave propagation and wireless communications systems. He is a registered member of the Council for the Regulation of Engineering in Nigeria (COREN). He is currently a Senior Lecturer in the Department of Electrical and Electronic Engineering, Ekiti State University, Nigeria. 